\title{
The Labor Relations Department of the Los Angeles Superior Court
}

\author{
Leonard Horwin*
}

\section{GENESIS}

For nearly a century and a half organized labor and employers in

the United States have battled over the issue of the closed union shop. ${ }^{1}$ Just after the turn of the Twentieth Century California was one of a small minority of jurisdictions in which the closed union shop found judicial sanctuary. ${ }^{2}$ Nevertheless, this controversy continued

*Member of the California Bar; formerly editor-in-chief, Yale Law Journal.

I The earliest recorded American labor case in effect held the closed union shop as well as any combimation to raise wages invalid. The laws of the umion ". . . leave no individual at liberty to join the society or reject it. ... They are not the laws of Pennsylvania.' Are we to have, 'besides our state legislature, a new legislature consisting of journeyman shoemakers?" " Cordwainers' Case ( $\mathrm{Pa}$. Recorder's Ct. 1805), analyzed by Nelles, The First American Labor Case (1931) 41 YaLE L. J. 165, 190. Accord: People v. Fisher (N. Y. Sup. Ct. 1835) 14 Wend. 9.

The closed shop was held vahd in the landmark dectsion of Shaw, C. J., Commonwealth v. Hunt (1842) 45 Mass. 111, 128. Later Massachusetts cases in effect repudiated Commonwealth v. Hunt on this point. E.g., Berry v. Donovan (1905) 188 Mass. 353, 74 N. E. 603 ; Folsom v. Lewis (1911) 208 Mass. 336, 94 N. E. 316.

As late as 1927 the inajority of reported cases held the closed union shop invalid either as promoting monopoly or as interfering with the non-union man's right to work or for divers other reasons. See cases collected in OAKEs, The LaW of Organized Labor AND INDUSTRIAI CONFLICTS (1927) \$292.

The present majority of cases hold closed umion shop contracts valid as a legitimate weapon in organized labor's "competition" with organized capital. See cases collected by Ziskind, The LAw BeHind Union AgreEMrents (Dept. of Labor, 1942) 12, n. 66, 68; ToRTs Restatement (Am. L. Inst. 1931) \& 788. The national and state labor relations acts adopted since 1933 specifically legalize closed shop contracts. Ziskind, op. cit. supra at 12, n. 69.

Generaliy, however, employers' associations continue to resist the spread of such contracts. Sen. Rep. No. 1150, 77th Cong. 2d Sess. (1942). Following the war-time policy laid down by the President of the United States the War Labor Board refuses to order creation of closed shop contracts where they have not heretofore existed. It orders, instead, so-called "maintenance of membership" contracts whereunder the employer agrees to enforce union memhership only among employees who are presently members or who thereafter express a desire to join.

To organized labor the closed umion shop means "open sesame" to the prestige, power and security that comes with union monopoly of the available jobs and eventual monopoly of the men to fill the jobs. For the same reason the idea has been anathema to employers and those employees who preferred the risks of independence.

2 Parkinson Co. v. Building Trades Council (1908) 154 Cal. 581, 98 Pac. 1027; Pierce v. Stablemen's Union (1909) 156 Cal. 70, 103 Pac. 324. 
to rage in California with a fury not excelled in any other jurisdiction. ${ }^{3}$ As late as 1940 California courts split widely as to whether 1933 legislation sponsored by organized labor to abolish the company union and anti-union (yellow dog) contract ${ }^{4}$ had also resulted in

3 "In California the employers' associations made even more of the closed-shop issue, if possible, than the employers' associations in other parts of the country. Conversely, the unions came to rely heavily upon the closed shop as a necessary bulwark of defense." SEN. REP. No. 1150, op. cit. supra note 1, at 55, 64.

It should be noted that the Parkinson Co. and Pierce cases, both supra note 2, expressly stated that a strike or boycott for closed shop was valid only in the absence of contract between the employer and his employees. The same reservation had also been made in the landmark case of Commonwealth v. Hunt, supra note 1. Hence, until the 1933 California legislation set out infra note 4, employers could and did exact antiunion (yellow dog) and company union contracts from their employees and on the basis thereof enjoin all strikes, picketing or boycotts which might interfere with performance of the contracts. Shafer v. Registered Pharmacists Union (1940) 16 Cal. (2d) 379, 383, 106 P. (2d) 403, 407. Cf. Patterson Glass Co, v. Thomas (1919) 41 Cal. App. 559, 183 Pac. 190 (holding that union's inducement of breach of employment contract is a tort in California); Note (1935) 23 CALIF. L. REy. 420, 425.

Following definition of the word "promise" in section 920, section 921 of the California Labor Code provides,

"Every promise made after August 21, 1933 between any employee or prospective eniployee and his employer, prospective employer or any other person is contrary to public policy if either party thereto promises any of the following:

"(a) To join or to renuain a member of a labor organization or to join or remain a member of an employer organization,

"(b) Not to join or not to remain a member of a labor organization or of an employer organization,

"(c) To withdraw from an employment relation in the event that he joins or remains a menber of a labor organization or of an employer organization.

"Such promise shall not afford any basis for granting of legal or equitable relief by any court against a party to such promise, or against any other persons who advise, urge, or induce, without fraud or violence or threat thereof, either party thereto to act in disregard of such promise."

Section 922 in effect makes it a misdemeanor for the enployer or his agents to violate section 921 .

Section 923 states,

"In the interpretation and application of this chapter [i.e., the chapter containing sections 920 and 923], the public policy of this state is declared as follows:

"Negotiations of terms and conditions of labor should result from voluntary agreement between employer and employees. Governmental authority has permitted and encouraged employers to organize in the corporate and other forms of capital control. In dealing with such employers, the individual unorganized worker is helpless to exercise actual liberty of contract and to protect his freedom of association, self-organization and designation of representatives of employment. Therefore it is necessary that the individual workman have full freedom of association, self-organization, and designation of representatives of his own choosing, to negotiate the terms and conditions of his employment, and that he shall be free from the interference, restraint or coercion of employers of labor, or their agents, in the designation of such representatives or in selforganization or in other concerted activities for the purpose of collective bargaining or other mutnal aid or protection." 
prohibition of the closed shop contract. ${ }^{5}$ In that year a reconstituted Califorma Supreme Court in five concurrently decided cases split four to three in reaffirming the legitimacy of the closed shop. ${ }^{\circ}$

5 Perhaps the first decision holding a closed shop contract void under Labor Code sections 921 to 923 was Berk v. O'Hara (San Bernardino Co. Super. Ct., May 10, 1938) L. A. Dallx J., Leonard, J. Denying the claim of defendant Retail Clerks Union that there a closed shop contract existed between plaintiff employer and the Union, the court held that even if such a contract had been consummated it would be void under the mentioned code sections. In enjoining picketing for a closed shop, the court stated, "The plaintiffs, if the contract is valid, have promised that they will make their help join the Union or discharge them. To secure performance of this promise on plaintiffs' part they nust interview their employes, and secure a promise from thein that they will join the Union. 'Every promise ... hetween any employe and his employer ... to join a labor organization . . . is contrary to public pohicy.' While the contract is not directly between the employer and einploye, its effect is the same and it is subject to the same objections."

The Alameda and Santa Clara County Superior Courts were in accord with Judge Leonard's conclusion. Shafer v. Registered Pharmacists Union and E. H. Renzel Co. v. Warehousenen's Union, both reversed by Califorma Supreme Court, infra note 6 .

The First District Court of Appeals came to the same conclusion. McKay v. Retail Auto Salesmen's Local (1939) 97 Cal. App. Dec. 122, 89 P. (2d) 426; E. H. Renzel Co. v. Warehousemen's Union (1939) 97 Cal. App. Dec. 132, 89 P. (2d) 435; C. S. Sunith Metro. Market Co. v. Lyons (1939) 97 Cal. App. Dec. 134, 89 P. (2d) 425.

Judge Elmer E. Robinson of the San Francisco County Superior Court reached an opposite conclusion in Hewitt v. Beauticians Urion No. 148-a (June 9, 1938) L. A. DAIIY J., stating, "The overwhelning trend of the courts is that labor units have the right to organize, and as part of that right to acquire new members by picketing. The court cannot believe the provisions of the Labor Code rehied upon by plaintiff became law for the purposes argued by plaintiff's counsel. The history of the statute shows that it was aimed to prohibit the use of yellow-dog contracts. Theretofore employers got promises from employes not to join unions. The statute was aimed to defeat this practice and to further collective bargaining. The court will not recognize a construction of the statute designed to prevent the solicitation of new members by picketing."

The decision of Judge Maurice T. Dooling of the San Benito County Superior Court, sitting pro tem in San Francisco in McKay v. Retail Auto Salesinen's Union (1938) 13 CAL. St. BAR J. 13, is in accord with Judge Robinson's decision.

6 McKay v. Retail Auto S. L. Umion (1940) 16 Cal. (2d) 311, 106 P. (2d) 373; E. H. Renzel Co. v. Warehousemen's Union (1940) 16 Cal. (2d) 369, 106 P. (2d) 1; Lund v. Auto Mechanics Union (1940) 16 Cal. (2d) 374, 106 P. (2d) 408; Shafer v. Registered Pharmacists Union, supra note 3 ; C. S. Smith Metro. Co. v. Superior Court (1940) $16 \mathrm{CaI}$. (2d) 226, $105 \mathrm{P}$. (2d) 587 (all holding that picketing or boycotting is protected by the 14th Amendment so long as the ineans used are peaceful and the object is "reasonably related to employment and to the purposes of collective bargaining", and holding further that peaceful picketing for a closed shop nreets the stated test).

In each of the five cases, decisions of the 1st District Court of Appeals had been set aside in order to permit hearing by the supreme court on the basis of importance of the issues involved. Arguments were presented, in addition to the five unions involved, by numerous intervening amici curiae on behalf of employers, organized labor and civil liberties groups. Due to changes in constituency of the court and inability of the reInaining judges to reach agreentent, the cases were reargued and resubmitted for decision three times over a period of approximately sixteen months. Final opinions totalled 153 
Nowhere in California was the closed shop controversy more pronounced than among the fifty judges of the Los Angeles Superior Court. Decisions varied from outright condemnation ${ }^{7}$ to outright sanction, ${ }^{8}$

pages of the official reports. Three of the final majority of four judges were new appointees of Democratic Governor Culbert L. Olson. One of the three, Judge Minor Moore, was serving pro tem on the supreme court.

${ }^{7}$ Judge Eminet H. Wilson in C. S. Smith Metro. Market Co. v. Lyons (L. A. Super. Ct. No. 517270, July 27, 1937) L. A. DaIrX J., rev'd, (1939) 97 Cal. App. Dec. 134,89 P. (2d) 425 , see note 5, supra. In enjoining picketing for a closed shop where none of plaintiffs' employes belonged or desired to belong to the union and no "dispute" existed between plaintiff employer and his employes, Judge Wilson made no mention of Labor Code sections 920 to 923 (cf., however, his later decision in Stockwell v. Vinstrand Theatres, infra note 11) but stated, "Conditioning the right to labor in one's chosen trade upon meinbership in any organization would amount to an extraneous limitation upon the inalienable right to acquire property which necessarily includes the right to labor for the means by which to acquire it."

While Judge Wilson was generally regarded as unequivocally opposed to the closed slrop, it is noteworthy that other judges of the same court came to like decisions on facts substantially similar to those in the C. S. Smith Metropolitan Market case but indicated doubt as to enjoining peaceful picketing or boycotting in cases where a "labor dispute" existed. See note 9, infra.

8 Judge Walter Desmond in Barraclough v. Local Joint Executive Board of Culinary Workers (L. A. Super. Ct. No. 420803, Aug. 25, 1938) L. A. DAIrY J. In refusing to enjoin a minority umion from picketing plaintiff's restaurants to compel plaintiff to sign a closed slop contract, Judge Desmond stated, "Our attention is called to Section 921 of the Labor Code of California, which declares contrary to public policy certain promises between employees and einployer, one of them being a promise to 'join or to remain a member of a labor organization or of an employer organization.' It is urged that the purpose aimed at in the present attempt to unionize plaintiffs' restaurants is the securing by plaintiffs of agreements from their employes to join a union . . . . But upon analysis it will be seen that the effort of the defendants here is not to obtain a promise between an employer and an employe or employes, but instead a contract between an einployer of labor and various unions, each of which represents the entire membership of the labor craft as it operates locally. Whether, if the agreement for a closed shop should be signed, any of the present employees of plaintiffs would decide to join or to remain unenbers of a umion, the future only could disclose. At any rate, each employee would be free, as he should be under Section 921 , to exercise his own judgment without making any promise to his employers."

In Glendale Lunber Co. v. Lumber, Mill \& Cabinet Workers (L. A. Super. Ct. No. 437252, April 21, 1939) L. A. DAIrY J., Judge Henry M. Willis refused to enjoin picketing for a closed shop where 3 out of plaintiffs' 7 employees were members of the union and on strike [but $c f$. his decision in the Olson's Bakery v. Bakery Drivers Local (L.A. Super. Ct. No. 452734, July 8, 1940) L. A. Dant J., where none of plaintiff's employees were members and no "dispute" existed between employer and employees]. Judge Willis stated, "There is nothing therein [in Labor Code sections 921 to 923] which condemns as unlawful a proposal by a labor union to an employer of labor that he agree to hire none but union labor, or that he discharge his non-union employees, so that he may employ only union labor. In the case at bar there existed a labor dispute between plaintiffs and their three union einployees."

Apparently to the same effect is the decision of Judge Reuben Schmidt in Employees of San Fernando Valley Times v. I. A. Printing Trades Council (April 11, 1940) 
with numerous variations on the major themes. ${ }^{\circ}$ Foremost among exponents of the first position was Judge Emmet H. Wilson, Judge of the Order to Show Cause Department in which temporary re-

L. A. Dartr J. (denying to non-union employees temporary restraining order against consummation of a closed shop agreement between defendant employer and defendant unions).

I In enjoining picketing for a closed shop where none of plaintiff's employees were members, none desired to belong and no "dispute" existed between them and their employer, Judge Henry M. Willis stated, "I an constrained to hold in this case, where there is no labor dispute between the employer and his employees, and a picket or boycott is being maintained by a group of third parties, advertising the employer to be 'Unfair to Organized Labor,' and the sole purpose of such activities is to compel the employer, under a pre-arranged plan and by concert of action on the part of the several parties thereto, to make a contract by which his employees will be deprived of their 'freedom of labor' and their individual or collective right to freely bargain with their employer as to terms and conditions of employment or for their other nutual aid or protection, and by which the eniployer becomes obligated to compel his employees to join a labor union or be discharged, that the purpose of defendant's activities is unlawful, denounced and conderinned by the Labot Code, and is a proper subject for equitabie relief." Olson's Bakery v. Bakery Drivers Local, suppra nöte 8.

In indicating per dicta that picketing for a closed shop is proper if a "labor dispute" existś betwéen an employer and his èmployees, Judge Chàrles S. Burnell stated, "It may be further noticed in passing that the term labor dispute' has a broader meaning than, and may include 'strike', and that a labor dispute may exist without a strike. It may well be that even though a strike, as such, has terminated and the places of the striking employeés bave been filled, a Tabor dispute' still exists. . . . The strike is not the only Weapon àvailable to labor. A labor dispute is not necessarily confined to the employer and his immediate employee: 'The purpose of a labor umion ... may justify what would otherwise be a wrong. . . It may be as interested in the wates of those not members, or in the conditions under which they work as in its own members because of the influence of one upon the other. . . . Unions believe that wages may be increased, collective bargaining maimtained only if umon conditions prevail, not in sone single factory but generally.'",

Los Angeles Athletic Club v. Joint Local Executive Board (L. A. Super. Ct. Nos. 419514, 419808, Dec. 7, 1937) E. A. DAIIr J, quoting with approval from Exchange Bakery \& Restaurant v. Rifkin (1927) 245 N. Y. 260, 157 N. E. 130.

In Cooper Co. v. Los Angeles Bldg. Trades Council (L. A. Super. Ct. No. 423641, Feb. 3, 1938) L. A. DaIry J., Judge Willian J. Palmer enjoined picketing to enforce a closed shop, but solely on the ground of misrepresentation in picketing. He stated, "It is an open question in 'this state whether 'peaceful picketing' is lawful as against an employer who is involved in no strike and no labor dispute with his employees. A strike of this kind usiually is engineered by persons who have no connection with the business involved, and is carried on for the purpose of 'umonizing' the picketed institution. Within recent nionths two scholarly Superior Court judges of our state have issued written opinions on this question, the two judges being in sharp disagreement in their conclusions. . . . Against picketing carried on, although peacefully, without there being a labor dispute between employer and employees, there have been two opinions by the Honorable Enumet $H$. Wilson, judge of this court. . . F Folding such picketing to be lawful, an opinion by the Honorable Maurice T. Dooling, judge of the Superior Court of San Benito County, is challenging. ... I find it dificult to locate an avenue of escape from the logit of Ju'dge Dooling's opinion and the authorities he tites to support it. 
straining orders and preliminary injunctions originated. ${ }^{10}$ Less than six months after the California Supreme Court had rendered its five decisions relegitimating the closed shop, Judge Wilson refused to be bound by the decisions, characterizing them as judicial legislation in direct violation of statutory language allegedly banning the closed shop. ${ }^{11}$ In the same period Judge William J. Palmer of the same court took a like position, labelling the supreme court's justification of picketing for a closed shop as a legitimate weapon in the "competitive struggle", as "communistic ideology which arrays employees against employers in a life-and-death class struggle."12 On the other

Briefly, the theory is this: Peaceful picketing is simply a method of publication."

But of. Judge Palmer's opinion later in the same case, infra note 12, holding that there is no such thing as peaceful picketing and that picketing is not a form of free speech.

In Weber Showcase \& Fixture Co., Inc. v. Millmen \& Cabinet Workers (L. A. Super. Ct. No. 423258, Feb. 17, 1938) L. A. DAII J J., Judge Palmer refused to enjoin picketing for the principal purpose of enforcing a closed shop. The ground for denial was that a bona fide strike was in progress notwithstanding the employer had replaced the strikers, and that peaceful picketing im aid of a bona fide strike is not enjoinable. He stated, "Peaceful picketing is lawful under our law as an incident of the strike."

10 Supra note 7. Judge Wilson consistently denied that strikes, picketing or boycotting were constitutionally guaranteed. Thus in citing defendants for contempt in Sontag Chain Stores v. P. M. Connolly (L. A. Super. Ct. No. 428985, Aug. 2, 1938) L. A. DaIrx J., he expressly refused to follow In re Lyons (1938) 27 Cal. App. (2d) 293, 81 P. (2d) 190, holding that picketing is an incident of the constitutional guaranty of free speech. Instead, Judge Wilson maintained that labor's weapons for infliction of injury were justified only where in aid of an existent strike resulting from a "labor dispute" between an einployer and his own employees. C. S. Sinith Metro. Market Co. v. Lyons, supra note 7; Cashis King Markets v. Retail Food Clerks Union (L. A. Super. Ct. No. 418385, Aug. 19, 24, 1937) L. A. Damx J.; Allen \& Huck v. Amalgamated Meat Cutters \& Butchers (L. A. Super. Ct. No. 418102, Aug. 24, Nov. 8, 1937) L. A. DarrT J.

Basing his conclusion on the non-union worker's alleged constitutional right to his labor (supra note 7) as well as Labor Code sections 921 to 923, Judge Wilson held that the closed shop was illegal per se. See also Bowers v. California Milling Corp. (L.A. Super. Ct. No. 434141, Jan. 17, 1939) L. A. DAIIY J.; Nutter v. Pacific Electric Ry. (L. A. Super. Ct. No. 450454, July 18, 1940) L. A. DAIIY J.; Hinckley v. Aunalgamated Meat Cutters \& Butchers (L. A. Super. Ct. No. 457508, Feb. 7, 1941) L. A. Danr J.

11 Stockwell v. Vinstrand Theatres (L. A. Super. Ct. No. 460498, March 26, 1941) L. A. DAIIY J. (granting to members of a C.I.O. projectionists' union representing all of defendant's employees, a preliminary injunction against discharging plaintiffs pursuant to closed shop contract with an A.F.I. projectionists union).

12 Ted R. Cooper Co., Inc. v. Los Angeles Bldg. Trades Council (L. A. Super. Ct. No. 423641, Jan. 6, 1941) L. A. DAIIY J., denying motion to vacate permanent injunction against picketing for a closed shop by a union representing none of plaimtiff's employees.

"The trial judge must determine for himself what the statutory law, fixed principles of equity, and the constitution require in a particular case, and in the performance of this duty, he looks to the decisions of appellate courts for guidance not for compulsion, 
hand, the presiding judge of the same court, Judge Rey B. Schauer, had aligned himself among the exponents of the constitutional sanctity of organized labor's weapons in the contest with employers. ${ }^{18}$

Two weeks after Judge Wilson refused to be bound by the California Supreme Court's approval of the closed shop, Judge Schauer ordered the creation of a Labor Relations Department of the Los Angeles superior court to which all "labor-industry and intra-labor controversies" involving temporary restraining orders, preliminary injunctions and the further proceedings therein were ordered trans-

nor for an excuse. ... Truth is that the term 'peaceful picketing' is a self-contradiction and aptly describes nothing that is known to man. . . . The doctrine that the end justifies the means, enunciated by our Supreme Court and by other Supreme Courts in connection with picketing, has . . . . its best known exponent in ... Machiavelli . . . and in our modern time ... Joseph V. Stalin ... Adolph Hitler and . . . Bemito Mussolini. ... There is yet no indication that a majority of the American people ... see anything in experiments in collectivism and totalitarianism. . . The American principle always has been that the interests of employer and employee are not adverse but are in cominon. But this is contrary to communistic ideology which arrays employees against einployer in a life-and-death class struggle. It is regrettable to note sone recognition of this ideology in the opinions under consideration, wherein employees are arrayed against employer 'in the struggle'. Picketing is one of the 'weapons' in this struggle. ... Is it not plain that there is only one barrier between our country and communism or totalitarianism of one form or other, with consequent regimentation and loss of freedom? That barrier, strange as it first might seem to some, is not the bill of rights. . . . It is the success of private business. . . . The margin between success and failure in business usually is a narrow one, and one that may quickly be destroyed by substituting coercion for judgment in management. When enployers reach the point where, against their wish, they are ready to finance a Hitler or a Mussolini into power, it is because the conditions requisite to manageinent have been destroyed. . .."

13 In People v. Young (L. A. Super. Ct. No. CR A 1497, Trial Court Nos. A-24826, A-24827, June 4, 1938) L. A. Darty J., Judge Schauer was part of the 2 to 1 majority of the appellate department of the Los Angeles Superior Court which voided provisions of a Long Beach Municipal ordinance prohibiting display of banners, etc. as part of picketing.

"While it is the duty of courts to uphold legislative enactments whenever that can be done without violence to fundamental constitutional standards, it is likewise their duty unhesitatingly to overthrow enactments which in effect would wrest from the citizenry their hard-won constitutional guaranties of freedom of life, liberty, and the right to possess property."

In People v. Gidaly (1939) $35 \mathrm{Cal}$. App. (2d), 758, 93 P. (2d) 660, the appellate department held the Los Angeles antipicketing ordinance unconstitutional. The majority opinion based the decision on the fact that the ordinance contained classifications having no reasonable relevance to its object. Judge Schauer concurred on the broader ground that prohibition of peaceful picketing violated the 14th Amendment.

In People v. Garcia (1939 37 Cal. App. (2d) 753, 98 P. (2d) 265, Judge Schauer rendered the opinion for a unaminous court voiding the remainder of the same ordinance on the broad ground that peaceful picketing is protected by the 14th Amendment. 
ferred. Concurrently, Judge Schauer ${ }^{14}$ designated as judge of the new department Judge Henry M. Willis, ${ }^{15}$ one of those whose sanction of the closed shop had preceded the five decisions of the California Supreme Court. ${ }^{16}$

The purpose of this article is appraisal of the work of the Labor Relations Department, first of its kind in the United States.

\section{STRICT VERSUS LIBERAL CONSTRUCTION OF PRO-LABOR IEGISLATION}

In an effort to prevent use of the Sherman Anti-Trust Law against labor unions, organized labor in 1914 lobbied the Clayton Act into federal law. ${ }^{17}$ Section 20 of the Act provided that no federal court could issue an injunction in a dispute between an "employer and eniployees". ${ }^{18}$ The United States Supreme Court construed the language strictly, confining it to disputes between an "employer" and his own "employees". ${ }^{19}$ Since a union's efforts to compel an unorganized employer to sign a closed shop contract does not constitute a dispute between the "employer" and his own "employees" or their representatives, section 20 was inapplicable. Hence injunctions could and did issue in a majority of instances, nullifying the purpose of

14 Now Presiding Judge of the third division of the Second District Court of Appeals.

15 Judge Schauer's order is reported in L. A. Daily Journal, April 10, 1941. While the order referred only to equity proceedings, the actual practice has been that substantially all labor matters, whether legal or equitahle in nature, are referred to the Lahor Rclations Department and are handled there from commencement to conclusion of trial court proceedings.

Judge Schauer's order stated, "It is hoped that through fairness of approach, thoroughness of investigation and firmness and uniformity of action, the destructive results both to persons and the public interest, which characterize less enlightened treatment [of labor cases], may be substantially avoided. In view of the increasing demands of labor controversies on the time of the court and the already very heavy calendars in Dept. 34, it was deemed unfair to Judge Wilson ... to ask him to take further time ... to devote to ... the work of this new department. . . Judge Henry M. Willis . . . has consented to take on these added responsibilities."

16 Supra note 8.

1738 STAT. (1914) 730, 29 U.S. C. (1940) § 52.

18 "That no restraining order or injunction shall be granted by any court of the United States ... in any case between an employer and employees, or between employers and employees, or between employees, or between persons employed and persons seeking employment, involving, or growing out of, a dispute concerning terms or conditions of employment. ..."

19 Duplex Co. v. Deering (1921) 254 U.S. 443, 479, Brandeis, J. dissenting, with Holmes and Clarke, J. J., concurring in his dissent. In justifying the adopted construction, the majority opinion stated, "Congress had in mind particular industrial controversies, not a general class war." Ibid. at 472 . 
the Clayton Act. ${ }^{20}$

Such instances demonstrated that unless a pro-labor legislative intent was clearly reflected in legislation, judicial interpretation and application of the legislation might well test the judge's social, economic or political preferences rather than his judicial capacity. ${ }^{21}$

In Nelson v. Los Angeles Building Trades Council ${ }^{22}$ the Labor Relations Department faced just such a gap between legislative intent and the language used.

Plaintiff contractor and builder was engaged in construction of a private aeronautics school near Lancaster, California, for the training of British and American war pilots under supervision of the United States Army. Although none of plaintiff's employees desired meinbership in defendant unions, the latter picketed plaintiff's job in a peaceful manner for the purpose of compelling him to sigu a closed shop contract. Driver members of the Teainsters Union refused to cross the picket lime. Accordingly delivery of essential materials was halted.

The Califorma Sabotage Prevention Act of 1941 provided severe punishment for persons interfering ". . with real or personal property with reasonable grounds to believe that such acts will ... interfere with the preparation of the United States or of any of the States for defense or for war. ..." The Act excepted, however, ". . . the rights of employees and their representatives to self-organization, to form, join, or assist labor organization, to bargain collectively through representatives of their own choosing, and to engage in concerted activities, for the purpose of collective bargaining or other mutual aid or protection" as well as "... the rights of employees, former employees, and their representatives to strike."23

Impressed by the fact that defendants were not "representatives" of plaintiff's employees and therefore not within the exception to the Act, Judge Willis granted plaintiff a temporary restraining order followed by preliminary injunction. ${ }^{24}$ The widely-publicized decision threatened considerable embarrassment for the attorney general of California who, in sponsoring passage of the Sabotage Prevention Act, had virtually guaranteed that it would not restrict the normal

20 FrANKFURTER and GreENE, The LABor InJuNCtion (1930) 99, 165, 206. Cf. opinion of Amidon, J., in Great Northern Ry. v. Brosseau (D. N.D. 1923) 286 Fed. 414.

22 (L. A. Super. Ct. No. 465879, Aug. 5, 1941) L. A. Daltr J.

21 Cf. FraniuruRTER and GrEeNE, op. cit. supra note 20, at 169.

23 CAL. GEN. LAWS (1941) act 8427 , \$§ 2, 11. (Italics added.)

24 (July 12, 1941) L. A. DaITY J. 
activities of organized labor. ${ }^{25}$ Embarrassment was averted when the court reversed its position, granting defendants' motion to dismiss for lack of jurisdiction.

In his final decision Judge Willis cited a communication he had received from the attorney general since the earlier rulings in the same case. The attorney general stated therein that the Act was not intended to be "... employed for determining labor disputes or any other purpose not positively stated therein."

The court also noted that construing the Act to prohibit peaceful picketing for a closed shop would render it unconstitutional under the California Supreme Court's 1940 decisions. ${ }^{28}$ Hence the term "employees" in the Act should be construed in "... its generic sense as a class engaged in labor ..." rather than "... its specific or more limited sense of employees of a certain employer."27

\section{A LITTLE WAGNER ACT FOR LOS ANGELES COUNTY?}

Organized labor in the courts with some success has preached the gospel of free competition including freedom to combine to compete and freedom to inflict injury upon employers and non-umon men incidental to competition. ${ }^{28}$ Simce, however, this same freedom included freedom of employers to discriminate against umion men, ${ }^{29}$ organized labor has preached quite another gospel in the legislature. Here it has

25 Attomey General Warren's Statement on Sabotage Law (July 26, 1941) L. A. DAIII J.

26 In A. F. of L. v. Swing (1941) 312 U.S. 321, even a state's common law policy of limiting peaceful picketing to disputes between the employer and his own employees was held to violate the due process clause of the 14th Amendment.

27 Supra note 24. "If the word 'workmen' had been used instead of the word 'employes' the meaning would have been clear, and all workmen and their representatives would have been definitely excluded from culpability under the Act. ..."

28 E.g. Commonwealth v. Hunt, supra note 1; Pierce v. Stablemen's Union, Parkinson Co. v. Building Trades Council, both supra note 2; Stillwell Theatre, Inc. v. Kaplan (1932) 259 N.Y. 405, 182 N.E. 63, cert. den., (1933) 288 U.S. 606; the five California Supreme Court decisions cited note 6, supra.

29 Such discrimination may include lockouts or anti-union (yellow dog) contracts or company unions imposed by the employer (note 3, supra) or the manifold other forms of discrimination which are now prohibited by national and state labor relations acts. Shafer v. Registered Pharmacists Union, supra note 3.

"In the absence of legislation laying down rules for the contest ... or where the acts complained of are outside the scope of such legislation, busimess men are apparently free to inflict damage in the struggle of competition so long as they abstain from violence, fraud or other unlawful conduct. ... The foregoing principles are relevant and have been applied to competition in the field of labor." C. S. Smith Metro. Market Co. v. Lyons (1940) 16 Cal. (2d) 389, 398, 106 P. (2d) 414, 420. 
insisted that free competition is impossible in fact until the individual worker's mequality of bargaining position is corrected by legislation cutting down the employer's bargaining power.

One result was that in 1932 orgamized labor lobbied into federal law the Norris-LaGuardia Act, prohibiting federal courts from enforcing anti-union (yellow dog) and company union contracts, ${ }^{30}$ and generally curtailing their power to issue injunctions in labor disputes. Concurrently similar laws were lobbied through various state legislatures including Wisconsin, ${ }^{31}$ Indiana, ${ }^{32}$ Washington ${ }^{33}$ and California. ${ }^{34}$ In California, however, the legislature approved only its preamble of policy" and two sections defining the word "promise" 30 and banning promises of employees to einployers to join or not to join a union. ${ }^{37}$ The rest of the Norris-LaGuardia Act, curtailing judicial power generally in labor disputes, was rejected. ${ }^{38}$

The Act's preamble as adopted in California states that in interpreting and applying the "chapter" of which it is a part, the public policy shall be to encourage employees to choose representatives and bargain collectively without employer interference. ${ }^{30}$ Reading the preamble together with the remainder of the "chapter", the California Supreme Court in its five 1940 decisions spelled out the meaning that for the purpose of protecting the employees' freedom to organize and bargain collectively, employers are forbidden to procure from employees promises to join a company-dominated union or not to join a bona fide union. ${ }^{40}$ Thus construed, the preamble of policy is given effect in interpreting and applying the operative sections of the same chapter, rather than being given independent effect.

3047 STaT. (1932) 70; § 3, 29 U.S. C. (1940) §§ 101, 103.

31 Trustees of Wis. S. F. of Labor v. Simplex Shoe Mfg. Co. (1934) 215 Wis. 623, 256 N.W. 56.

32 Local 26, Nat' Bro. of Op. Potters v. Kokomo (1937) 211 Ind. 72, 5 N.E. (2d) 624.

33 Blanchard v. Golden Age Brewing Co. (1936) 188 Wash. 396, 63 P. (2d) 397.

34 Supra note 4.

35 CAL. LABOR Code (1938) § 923.

36 Ibid. \$ 920.

37 Ibid. $\$ 921$; see also $\S 922$.

38 CaL. Assearbly BIII No. 315 (1933). See Shafer v. Registered Pharmacists Union, supra note 3.

39 Supra note 4.

10 See Shafer v. Registered Pharmacists Union, supra note 3, at 385, 106 P. (2d) 407. The court held, however, that an employer could vahilly sign a closed shop agreement with a bona fide union requiring the employer to compel his employees to join such union. 1bid. at 387,106 P. (2d) at 408. 
In a Wisconsin decision, however, the preamble was given independent effect by granting to labor unions an injunction restraining an employer from threateming to discharge his employees for union activities or otherwise interfering with their freedom of choice of collective bargaining representatives. ${ }^{41}$ In so doing, of course, the Wisconsin Supreme Court in effect legislated sections 8 (1), 8 (2) and 8 (3) of the National Labor Relations Act ${ }^{42}$ into Wisconsin law. This is anomalous. For if the decision is sound, enactment of these sections of the National Labor Relations Act in 1935 was unnecessary since the Norris-LaGuardia Act had already accomplished the same result in 1931 by a mere declaration of policy.

Relying on the Wisconsin decision as persuasive authority, ${ }^{43}$ the Los Angeles Superior Court has gone Wisconsin one better. Not only did it in effect legislate the mentioned sections of the National Labor Relations Act into California law, ${ }^{44}$ but it also adopted sec-

41 Supra note 31.

4249 STAT. (1935) 452,29 U.S.C. (1940) $\$ 158$ provides,

"It shall be an unfair labor practice for an employer-

"(1) To interfere with, restrain, or coerce employees in the exercise of the rights guaranteed in section 157 ['... self-organization, to form, join, or assist labor organizations, to bargain collectively through representatives of their own choosing, and to engage in concerted activities, for the purpose of collective bargaining or other mutual aid or protection....']

"(2) To dominate or interfere with the formation or administration of any labor organization or contribute financial or other support to it. ...

"(3) By discrimination in regard to hire or tenure of employment or any term or condition of employment to encourage or discourage membership in any labor organization...."

43 The Los Angeles court also cited Texas \& N. O. Ry. v. Railway Clerks (1930) 281 U.S. 548; Virginian Ry. v. Federation (1937) 300 U.S. 515; Blanchard v. Golden Age Brewing Co., supra note 33. These decisions, however, are not support for the proposition that independent effect is to be given a legislative statement of policy guiding an enactment. The first two cases imvolved sections 2 (3) and 2 (9), respectively, of the National Railway Labor Act [44 STAT. (1926) 577, 45 U.S. C. (1940) § 151]. Neither of the mentioned sections involved a mere declaration of policy. The first imposed a specific prohibition, the second a specific affirmative duty.

The Blanchard case is completely irrelevant. It merely held that Washington's enactment of a state Norris $\mathrm{La}$ Guardia Act was unconstitutional because it attempted to curtall judicial power created by the state constitution.

44 Willis, J., in Coleman v. Back (L. A. Super. Ct. No. 473191, March 14, 1942) L. A. DAIrY J., granting the A. F. L. Cleaners \& Dyers Union an mjunction against the employer's threat to discharge for union activities and otherwise interfere with his employees' freedom of choice.

See prior application of the same principle in Althof v. Western Aeronautical Supply Mfg: Co., Inc. (L. A. Super. Ct. No. 460291, Feb. 19, 1941) L. A. DaIIY J., where Emmet H. Wilson, J. stated, "Declarations of public policy have the force of law and 
tion $8(5)^{45}$ of the Federal Act by requiring an employer to bargain

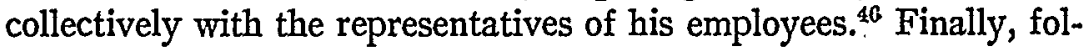
lowing a lead previously established by Judge Emmet Wilson, ${ }^{47}$ the Labor Relations Department in effect adopted the remedy sections of the Federal $\mathrm{Act}^{4 \mathrm{~S}}$ by granting a mandatory injunction for reinstatement and back pay to employees discharged for union activities. ${ }^{40}$

Thus a platitudinous preamble is converted into operative law by stating that "Declarations of public policy have the force of law ..." and equity will provide a remedy where "... neither specific remedy nor procedure is established by law. . . " that employees should be free to pick representatives to "negotiate" on their behalf, is converted into a duty of employers to bargain collectively simply by noting that "The word 'negotiate' necessarily imports two or more parties in conference over some affair or busi-

will be given effect by means of appropriate judicial proceedings. When new conditions arise a court of equity, although neither specific remedy nor procedure is established by law, will so chart its course and extend its jurisdiction as to sustain and enforce rights when justice cannot be obtained in any other form."

45 Wis. Stat. (1937) \& 111.08, making it ". . . an unfair labor practice for an employer. ... To refuse to bargain collectively with the representatives of his employes. ..." subject to the provisions of section 9 (a).

46 Sitkin v. International Fur Workers Union (L. A. Super. Ct. No. 446361) Emmet H. Wilson, J.'s opinion on prehminary imjunction in (1939) 5 Lab. Rel. Rep. 495; Willis, J.'s opinion on permanent injunction in (Jan. 4, 1940) L. A. DAItr J. Cf. Peirson M. Hall, J., in Shapiro v. Amalgamated Watchmaker's Union (L. A. Super. Ct. No. 446190, Feb. 9, 1940) L. A. Dater J.

The mentioned opinions rest on the non-sequitur that because Labor Code section 923 declares a public policy that the employee shall be "free" to choose representatives "to negotiate the terms and conditions of his employment" (supra note 4), thereforo a duty of the employer must be implied "to entertain and, in good faith and witb common business courtesy, jom in a proposed negotiation." See Willis, J.'s opinion, sutpro.

47 Geitgey v. Bay Cities Transit Co. (April 5, 1941) L. A. DaItx J.

4949 STAT. (1935) $453, \S 10$ (c), 29 U.S.C. (1940) §160(c):

"... If upon all the testimony taken the Board shall be of the opinion that any person named in the complaint has engaged in or is engaging in any such unfair labor practice, then the Board shall state its findings of fact and shall issue and cause to be served on such person an order requiring such person to cease and desist from sucl unfair labor practice, and to take such affirmative action, including reinstatement of employees with or without back pay as will effectuate the policies of this chapter. ..."

49 Daniels v. Table Linen Supply Co. (L. A. Super. Ct. No. 465821, April 28 and 29, 1942) L. A. DAIr J. Without such renedy, declared Willis, J., the public policy against interference by the employer would be worthless. A prohibitory injunction after the employer had discharged an employee for union activity would be "s... Iocking the barn door after the loorse had been stolen.' The only substantial relief . . . . is annulment of such discharge and reinstatement to the former employment, with lost pay and an injunction not to repeat such wrongful discharge."

60 Wilson, J. in Althof v. Western Aeronautical Supply Mfg. Co., supra note 44. 
ness." "11 Finally, duty is implemented by penalty simply by characterizing any remedy without reinstatement and back pay as "Locking the barn door after the horse has been stolen."

Thus a proposed Little Wagner Act for California which failed to pass the state legislature in 1937 and again in $1939^{53}$ succeeds in passing the judiciary in 1942.

\section{COURT CONDUCTED EMPLOYEE ELECTIONS FOR LOS ANGELES COUNTY?}

In order to determine with whom the employer inust bargain collectively, the National Labor Relations Act provides a procedure for Board-conducted elections of representatives by employees in an appropriate bargaining unit..$^{54}$ The employer who fails to bargain with the representatives thus elected invites a cease and desist order for unfair labor practices under section 8 (5) of the Act.

Since the Labor Relations Department of the Los Angeles Superior Court nil effect has construed section 8 (5) into California law, the question arises with whom must the employer bargain collectively? For the preamble in section 923 of the California Labor Code, uses the term "representatives" without defining either the unit to be represented, ${ }^{55}$ the minimum percentage of employees required to elect the representatives, ${ }^{5 B}$ or the tribunal to decide who is representative. It follows that in order to enforce the duty to bargain collectively, the court will have to put content into section 923 by deciding who are representatives, and in a proper case, who are not.

In short, the corollary of construing section 8 (5) of the National Labor Relations Act into California law is that the court will have to assume a responsibility such as that of the National Labor Relations Board. Further, it is possible that in order to enforce the duty

61 Willis, J. in Sitkin v. International Fur Workers Union, supra note 46.

62 Willis, J. in Daniels v. Table Linen Supply Co., supra note 49 . The decision disregards without mentioning the conventional doctrine that equity will not compel either master or servant to enter or remain in a master-servant relationship. O'Brien v. Perry (1900) 130 Cal. 526, 62 Pac. 1120; Cat. Civ. Code $\$ 3390$ (1) (2); Contracts RestateMIENI (Am. L. Inst. 1932) §379.

63 CAL. Assearbir BIIIS Nos. 538 (1937) and 579 and 1065 (1939).

$04 \$ 9$ (a)-(d).

56 Section 9 (b) of the National Labor Relations Act authorizes the Board to determine whether ". . . the unit appropriate for the purposes of collective bargaining shall be the employer unit, craft unit, plant unit, or subdivision thereof."

56 Section 9 (a) of the National Labor Relations Act gives to the representatives of ". . the majority of the employees in a unit appropriate for such purposes ...", the right of exclusive representation "... of all the employees in such unit for the purposes of collective bargaining...." 
to bargain collectively with a representative union the court must enjoin picketing or boycotting by an unrepresentative one which interferes with the court's enforcement of the employer's duty. ${ }^{57}$ Likewise, once having chosen the representative union, the court must protect a compliant employer against picketing or boycotting by an unrepresentative union for the purpose of procuring recognition or a closed shop. ${ }^{58}$

This follows logically from the holding of the Labor Relations Department in Pfeiffer v. Borun Bros. ${ }^{59}$ that an unrepresentative union may be denied enforcement of a closed shop contract where the employer sets up illegality as defense to the union's action for specific performance; likewise from its holding in Kaufman v. Amalgamated Meat Cutters $\mathcal{E}$ Butchers ${ }^{60}$ that an injunction against picketing or boycotting will issue in favor of an injured employer after the $\mathrm{Na}$ tional Labor Relations Board has assumed jurisdiction of an election proceeding, notwithstanding no representative has yet been certified,

\begin{abstract}
"Such relief would not lack the essential element of due process required by the Fourteenth Amendment, in deprivation of a constitutional riglit guaranteed by the First Amendment of the Federal Constitution, which, however, is not absolute-but would be in direct aid and enforcement of a public policy, declared by both the Federal and the California State governments, and to prevent irreparable injury and loss to plaintiffs, while preserving for the National Labor Relations Board an untrammeled jurisdiction to determine in the meantime the controversy herein as to whom shall be designated as bargaining agent for plaintiffs' employees. ... .
\end{abstract}

57 Cf. Union Premier Food Stores v. Retail Food C. \& M. Union (C.C.A. 3d, 1938) 98 F. (2d) 821, aff'd, (C.C.A. 3d, 1939) 101 F. (2d) 475, but rev'd per curiam, (1939) 308 U.S. 526, on the ground that the case had beconie moot (holding that once the $\mathrm{Na}$ tional Lahor Relations Board has assumed jurisdiction of election proceedings, there is no longer a "labor dispute" within the meaning of the Norris La Guardia Act and hence the federal court nray enjoin picketing).

68 Cf. Bloedel Donovan Lumber Mills v. International, etc. (1940) 4 Wash. (2d) 62,102 P. (2d) 270 (enjoining picketing by ininority C. I. O. union after certification of A. F. L. majority union by National Labor Relations Board).

69 (L. A. Super. Ct. No. 475320, June 10, 1942) L. A. DaIfY J. “. . . this court clearly has jurisdiction in equity to hear and determine the question of the validity and enforceability of the contract sought to be enforced, and to that end apply the provisions of the National Labor Relations Act in respect to unfair labor practices to the facts developed in evidence at the trial. That act empowers tbe Board to prevent any person from engaging in unfair labor practice, and declares such power to be exclusive, but it does not, as a consequence, oust a state court of its equitable jurisdiction to determine whether or not to enforce a labor union contract relied upon by a plaintiff in any action for specific performance thereof. ..."

60 (L. A. Super. Ct. No. 473834, April 24, 1942) L. A. DaIrY J. 
"The obligation imposed by this act [National Labor Relations Act] to treat only with the true representatives is exclusive and hence imposes the negative duty to treat with no other. (N.L.R.B. v. Jones \& Laughlin Steel Co., 301 U.S. 1, 44). An employer who enters into a labor union contract with an unauthorized agent of his employees has interfered with, restrained and coerced his employees in the exercise of the rights of self organization and collective bargaining through a selected agent as guaranteed in Section 7 of such act, and any such contract would be void (Warehousenen's Union v. N.L.R. B., 121 F. (2d) 84). Under section 923 of the California Labor Code, this same act is denounced as against public policy.

"It follows in logical sequence that, inasmuch as it is unlawful for the employer, engaged in interstate conmerce, to commit such unfair labor practice, defined as part of the public policy in labor relations, it would be unlawful for unions to picket, boycott or use other forms of economic pressure on such employer to compel hin to negotiate or execute a contract with a union which does not represent a inajority of his employees, and thus engage in an unfair labor practice, condemned by the statute and in direct violation of a public policy." 11

But while court-conducted elections and restraint of picketing or boycotting both pending and after selection of the majority representative are logical, on the appearance of things they disregard precedent. For the California Supreme Court in 1940 concluded that picketing for a closed shop contract is within the constitutional guaranty of free speech even if none of plaintiff's employees are members and none desire membership, ${ }^{62}$ likewise even if plaintiffs are themselves employees who claim to be represented 100 per cent by another union..$^{83}$ The sole exception, indicated by dicta only, was if plaintiff were an employer innocently injured as the result of a true jurisdictional dispute between rival umons. ${ }^{64}$

61 lbid. (Italics added.) In Adkins v. Western Pipe \& Steel Co. (L. A. Super. Ct. No. 476502, June 7, 1942) L. A. DaIIX J., Willis, J., denied a C. I. O. union's prayer for restraint against performance of an A. F. L. union's closed shop contract pending outcome of a Board-conducted election. The plaintiff's prayer was based upon the alleged invalidity of the contract as an unfair labor practice of the defendant employer. In denying relief, the court pointed out that employees and their representatives such as the plaintiff union have an exclusive remedy under the National Labor Relations Act for redress against employers. The Kaufman case, supra note 60 , was distinguished on the ground that the National Lahor Relations Act grants no remedy to an injured employer, thus compelling him to resort to equity.

62 C. S. Smith Metro. Market Co. v. Superior Court, supra note 6.

Q3 McKay v. Retail Auto S. L. Union, supra note 6.

64. "It is also urged that the complaint shows that the plaintiffs have established thrir own lahor organization to bargain collectively with the employer and that under 
Since the Los Angeles Superior Court is ordinarily bound by precedent of the California Supreme Court, it follows that the Labor Relations Department is in the position of commanding the employer to bargain with the representatives of his employees ${ }^{85}$ while at the same time telling him that it is part of the free speech of an unrepresentative union to exert pressure short of violence to compel the employer to deal with the unrepresentative, and accordingly disregard the representative union. ${ }^{88}$ However, in the circumstances suggested by the Supreme Court dictum, "a jurisdictional dispute", the Labor Relations Department could have partially solved the apparent dilemma. Thus in Los Angeles County Fair Ass'n v. Pomona Valley Central Labor Council, ${ }^{67}$ where defendants were unrepresentative unions picketing to compel the employer to cancel a closed shop contract with a bona fide representative union and sign one with defendants instead, the court could have held that an employer thus injured is the victim of "a true jurisdictional dispute" and accordingly entitled to injunctive relief. But Judge Willis denied relief to the employer, stating that when the Supreme Court referred to "true jurisdictional dispute" it

"... had in mind an internal union labor dispute over the so-called jurisdictional right of a particular craft or trade union local to a particular class of employment or employment in a particular territory. The dispute in this case is a labor dispute and is not a jurisdictional dispute."

From Judge Willis' decision it follows that the employer who obeys the mandate to bargain collectively will be protected from in-

such conditions any attempt by the defendants to 'unionize' them or to interfere with their employment relations is unlawful. But there are two fundamental and equally conclusive reasons why this contention cannot be sustained.

"First, this is a suit in which the employees only are seeking relief. The employer, although named as a party defendant, did not make an appearance in the trial court. Assuming, without deciding, that an employer may be entitled to equitable protection from imjury to his business as the result of a true jurisdictional dispute between rival unions, it is, nevertheless, the settled law of this state that a group of the employer's workers can claim no such protection. ... . It must be decmed settled, therefore, that one labor union may not bave the protection of equity against the lawful conpetitive activities of a rival union.

"Moreover, the facts alleged by the plaintiffs do not sufficiently show that they have organized a bona fide independent labor union." McKay v. Retaii Auto S.L. Union, supra note 6 , at $328,106 \mathrm{P}$. (2d) at 382 .

05 Supra note 46.

66 Willis, J.'s decision in Stockwell v. Vinstrand Theatres (L. A. Super. Ct. No. 460498, June 5, 1941) L. A. DaIry J.

67 (L. A. Super. Ct. No. Pomo. C-412, Aug. 1, 1942) L. A. Dantx J. 
jury by an unrepresentative union if the latter is a local of the same parent organization as the union recognized by the employer, but not otherwise. Inasmuch as the bulk of jurisdictional disputes in recent years have been between competing kinds of unions, usually lacking a common parent, it is apparent that the rule of the Labor Relations Department offers little consolation to the employer.

In Nash Co. v. Retail Food Clerks' Union ${ }^{6 s}$ the Labor Relations Department again had an opportunity partially to resolve the dilemma in treatment of the employer. The immediate problenı was whether to enforce a Pasadena ordinance banning picketing or boycotting for the purpose of conpelling an employer to sign a closed shop contract with a union representing less than a majority of his employees.

The court could have held that the word "representatives" in Labor Code section $923^{69}$ means representatives of a majority of the employees in an appropriate umit. ${ }^{70}$ To interpret the word otherwise would mean either that the employer must bargain with any representative, no matter how small its following, or that he need not bargain at all unless the representative has a 100 per cent following. The first alternative would be impractical and onerous; the second would largely nullify the duty to bargain collectively. No California Supreme Court decision barred the Labor Relations Department from adopting the "majority" rule, inasmuch as no such decision has yet even inferred the duty to bargain collectively from section 923 . Once having adopted the "majority" rule, the Labor Relations Department could have decided that the Pasadena ordinance was consistent with state policy and constitutional, at least insofar as it prohibited picketing or boycotting by an unrepresentative union after the employer had recognized a bona fide representative union. ${ }^{71}$ This would have given effect to the dictum in the $M c K a y$ case that relief might be available to an employer innocently hurt by "a true jurisdictional dispute between rival unions."

Instead, however, the Labor Relations Department held the ordinance wholly unconstitutional on the grounds of inconsistency with

es (L. A. Super. Ct. No. 477763 , July 7, 1942) L. A. DaIry J.

69 Supra note 4.

70 The National Labor Relations Act adopts the "majority" rule. Supra note 56.

71 The problem of severability of the constitutional from the unconstitutional phases of the ordinance, not having been raised, is not discussed here. 
paramount state policy as declared in Labor Code section $923,{ }^{72}$ and likewise with the First (sic. $)^{73}$ and Fourteenth Amendments to the Federal Constitution. ${ }^{74}$

In Stockwell v. Vinstrand Theatres ${ }^{75}$ members of a C.I.O. Motion Picture Projectionists union constituting all of defendant employer's projectionists, had been demied admission to the A.F.L. Projectionists Umion and sought to enjoin their employer from discharging them upon demand of the A.F.I. union pursuant to its closed shop contract with the employer. To grant the plaintiffs relief would have violated the Califorma Suprenie Court's conclusion ". . . that one labor union may not have the protection of equity against the lawful competitive activities of a rival union." To deny relief was to disregard the obvious fact that the duty to bargain collectively with the representative union-here the C.I.O. union, is violated where the employer contracts with an unrepresentative union-here the A.F.L. union. ${ }^{76}$ The case thus aptly illustrated the dilemma in treatment of the eniployer, denionstrating that the duty to bargain collectively

72 Supra note 68. "And in its prefatory part or preamble it [the ordinance] declares the public policy of the city in respect to rights of employees to self-organization, and to designation of bargaining agents by employees, and in respect to non-interference therewith, in the same language and to the same effect as declared by the state legislative body in Section 923 of the Labor Code, with the exception of the designation therein of those who are forbidden to interfere with the exercise of such rights. In the state law such interference is limited to employers and their agents, while in the ordinance it is extended to include everyone. . . . This is not 'such new and additional regulations in and furtherance of the purpose of the general law as may seem fit and appropriate to the necessities of the particular locality, ... but a drastic and complete change of public policy, inconsistent with the state's declared policy. Powers exercised by a municipality in respect to an appropriate subject matter must be consistent with the general laws and public policy of the state."

73 The First Amendment to the Federal Constitution limits only federal, not state action. Barron v. Baltimore (1833) 32 U.S. (7 Pet.) 242.

74 Supra note 68. "A majority group of employees by representation may lawfully picket or boycott, but a minority are prohibited from such activities. Under the decisions of the Supreme Court of the United States in the cases of Thornhill v. Alabaina, 310 U.S. 88, and Carlson v. California, 310 U.S. 106, the fundamental rights of free speech and assemblage, as exercised by means of picketing and in boycott, granted by the First Amendment to the Constitution of the Umited States, and guaranteed against abridgment or less under the Fourteenth Amendment, were declared to be secured to 'every person'. Without further discussion we must conclude that the denial of such rights, exercised peacefully and honestly in picketing or boycott activities, to members of a minority of employees is an abridgment of such rights. ..."

75 Supra note 66 . Plaintiffs had previously been granted a preliminary injunction by Judge Emmet H. Wilson, supra note 11.

76 Kaufman v. Amalgamated Butchers, supra note 60 , and quotation in text. 
cannot coexist with the Supreme Court rule. Judge Willis denied the injunction, thus choosing to follow the Supreme Court rule. ${ }^{77}$

The enigmatic fact thus remains that on the one hand the Labor Relations Department demands that the employer refrain from interfermg with his employees' freedom of choice, ${ }^{78}$ demands that he bargaim collectively with the representatives thus freely chosen, ${ }^{78}$ threatens him with punishment for violations of these duties including reinstatement and back pay. ${ }^{80}$. On the other hand, notwithstanding the employer has complied with his duty by contracting with the representative union, he is told by the same court that it is legal for him to sign a closed shop contract at the behest of an unrepresentative union giving his employees a choice between joining or being discharged, ${ }^{81}$ and that hence the unrepresentative union may picket and boycott him to compel such a result. ${ }^{82}$

\section{UNFAIR LABOR PRACTICES BY UNIONS? ${ }^{83}$}

Restraint of trade.-The courts have frequently held that the closed union shop constitutes an illegal monopoly and its enforcement

77 The court noted, however, "Whether an action hes in equity to annul such contract on the ground that it creates an unlawful monopoly is not a proper question in this case and is not here considered or settled."

78 Supra note 44.

${ }^{79}$ Supra note 46.

80 Supranote 49.

81 Supra note 66.

82 Supra note 67. Yet in Adkins v. Western Pipe \& Steel Co., supra note 61, Judge Willis quoted with approval from Teamsters v. United Brewery Workers (C. C. A. 9th, 1939) 1 C. C. H. Labor Cases 1269 , holding that after the National Labor Relations Board had certified a nlajority representative, employees threatened with discrimination might enjoin both the employer and an unrepresentative union seeking to enforce a closed shop "However, if the relationship, the existence of which is certified by the Board, be unlawfully interfered with, and if the Board's powers afford inadequate protection to the employees and their union agent, it may well be that under the principles of equity the aid of the courts may be invoked.")

83 In American Umion Alliance v. A. F. of L. (L. A. Super. Ct. No. 474935, April 29, 1942) L. A. Darly J., Judge Willis apparently held that a union as well as an en1ployer could be guilty of unfair labor practices under Labor Code section 923. The court granted an injunction in favor of a company union and its independent afiliate against defendant unions' threats of violent interference with plaintiffs' self-organization, stating, "Herein, one nuust recognize that plaintiffs possess, as an acknowledged property right, the guaranteed right to labor and earn a livelihood with their own hands, and that they are under the protection of the declared public policy of this state to enjoy the right of self-organization and to have bargaining representatives of their own choosing, as set forth in section 923 of our Labor Code. The alleged purpose and efforts of defendants to force plaintiffs by continued threats of bodily injury over a long period 
a conspiracy as against non-members and the public. ${ }^{84}$ Judges who believed in laissez faire for unions as well as employers, however, held that the unions' effort to procure employment for their members "to the exclusion of those not associated with them" was merely "... the struggle of competition, no more to be frowned upon where the subject of trade is labor than where it is a specific commodity." 86 Pushed to its logical extremity this liberal doctrine would approve a union's effort to promote its members' self-interest by denying nonmembers the opportunity to become members as well as the jobs.

The law, however, must be realistic as well as logical, if it is to survive. Hence various courts have analogized unions which maintain a closed shop as well as closed niembership rolls, to merchants with a corner on essential merchandise (jobs) who have agreed to restrain trade therem. The result is a mixed doctrine to the effect that closed shops alone are valid, as are closed membership rolls alone; but when combined, they constitute unlawful monopoly. ${ }^{86}$ This doctrine is anonialous when coupled with the conclusions of many courts and legislatures that labor is not a commodity or subject of trade. ${ }^{87}$ It is, however, a socially healthy rule and appears to be generally accepted. ${ }^{88}$

In Dyar v. International Photographers Union ${ }^{80}$ and Bautista v. Milk Drivers Union ${ }^{90}$ the Labor Relations Department considered two aspects of monopoly in labor unions.

In the Dyar case defendant A.F.L. still photographers union by means of a closed shop condition controlled between 60 and 75 per cent of all still camerainen jobs in motion picture studios in Los

of time, and by the fear engendered thereby, to abandon their own organization and representatives and to join defendant union are unlawful, as against public policy and as constituting a nuisance and may be enjoined by a court of equity." (Italics added.)

84 See cases collected in OAEEs, loc. cit. supra note 1.

85 Parkinson Co. v. Building Trades Council (1908) 154 Cal. 581, 607, 98 Pac. 1027, 1038, quoted with approval in McKay v. Retail Auto S. L. Union, supra note 6. Accord: Commonwealth v. Hunt, supra note 1; Holmes, J., dissenting in Vegelahn v. Guntner (1896) 167 Mass. 92, 104.

86 See cases summarized in 1 Tetrez, Labor Dispotes and Colflective BaroanNinc (1940) 285, § 99.

87 E.g., Clayton Act §6, 38 StaT. (1914) 730, 15 U.S. C. (1940) § 17 ("That the labor of a human being is not a commodity or article of commerce . . ."); CAL. GEN. Laws (1937) act 8702, § 13; Robinson v. Hotel \& Rest. Eunployees (1922) 35 Idaho 418, 207 Pac. 132.

88 TORTS Restatenuent (Am. L. Inst. 1939) \$ 788.

89 (L. A. Super. Ct. No. 471686, Feb. 24 and 25, 1942) I. A. Darly J.

80 (L. A. Super. Ct. No. 471686, March 16, 1942) L. A. DAIIY J. 
Angeles County. Although plaintiff was admittedly well qualified, defendant repeatedly refused his applications for membership with the result that plaintiff had been denied employment in a motion picture studio for several years. Judge Willis enjoined the union from interfermg with employment of plaintiff by any studio willing to employ him, so long as the union kept its membership rolls closed. ${ }^{91}$ The court demed damages, however, on the ground that the monopoly injured merely a public right rather than any private right of plaintiff. ${ }^{22}$

This limitation of relief is questionable. An individual injured by monopoly at common law was entitled to damages. ${ }^{93}$ No California legislation confines to the public the right as against monoplistic practices of a union. ${ }^{94}$ On the contrary, the law governing unions has generally treated them as private clubs with corresponding liberty of contract, rather than charging them with public duty. ${ }^{95}$ Moreover, even where, as in the case of nuisances, the law expressly defines a right as public and limits private redress to instances where the violation is "specially injurious" to the individual, the individual thus injured is permitted any "civil" relief, legal or equitable..$^{9 B}$ Finally,

91 "This court recognizes its lack of power to compel the defendant union to admit plaintiff or any other applicant to membership in its ranks. But this court may forbid the union from proceeding to enforce the condition of obnoxious monopoly herein found to exist as long as its membership rolls are closed, by mterfering in any manner or by any means, with the right of plaintiff to apply for and secure employment as still cameraman in any studio producing moving pictures in Los Angeles County, which desires and chooses to employ him."

92 "It was the combination of the closed shop condition and the closure of menbership in the union, each of which was by itself lawful, which resulted in the monopoly which is declared obnoxious and unlawful, because it is detrimental to public welfare. The injury resulting therefrom was to the public, and that alone converted the original monopoly from a status of right to that of wrong. To remedy that the plaintifi, as a party beneficially interested, is entitled to injunctive process only, and not to damages. ... In seeking and securing the judicial abolition of this unlawful monopoly, plaintiff sues as one of the members of the public, personally and directly injured thereby, and in such action, individual damage is not a proper subject of relief."

93 Dyer's Case (1415) Pasch. 6 Y. B., 2 Hen. V. f. 5, pl. 26.

94 In fact, the only legislative prescription of monopolies in California specifically grants the right of individual suit for damages: Cartwright Act, CAd. Gen. Laws (1937) act $8702, \S 11$.

95 Otto v. Tailors P. \& B. Union (1888) $75 \mathrm{Cal} .308$, 17 Pac. 217; Greenwood v. Building Trades Council of Sacramento (1925) 71 Cal. App. 159, 233 Pac. 823; McConville v. Milk Wagon Drivers' Union (1930) 106 Cal. App. 696, 289 Pac. 852; Hughes v. American Trust Co. (1933) 134 Cal. App. 485, 25 P. (2d) 491; Note (1936) 45 Y YrE L. J. 1248, 1263-71.

86 Johnson v. V. D. Reduction Co. (1917) 175 Cal. 63, 164 Pac. 1119; Cad. Crv. CoDE $\S \S 3480,3491,3493$. 
the limitation imposed tends to nullify the value of the relief. For the offending union takes the risks of an injunction operative only in the future. On the other hand, the plaintiff who presumably is already unemployed and impoverished by the union's conduct incurs the additional and immediate cost of litigation. Even if victorious, his reward is only that if he finds a job, the injunction may aid him.

In the Bautista case ${ }^{97}$ a milk wagon drivers union having closed shop contracts with 95 per cent of the milk brokers in Los Angeles County rejected plaintiffs' applications for membership on the ground that they were "independent peddler distributors" and demanded instead that plaintiffs hire union members to drive their trucks. Plaintiffs made their livelihood by hiring no employees and driving their own trucks. To enforce its demand the union caused the milk brokers to refuse sale of dairy products to plaintiffs. Plaintiffs requested injunctive relief to prevent.complete stoppage of their business.

Plaintiffs in such a case are self-employed entrepreneurs working for profit rather than workers employed by another for wages. It is therefore arguable that plaintiffs have different interests and are not properly eligible for membership in a union of employed workers. ${ }^{88}$ If so, a union rule excluding them could not be said to create a monopoly of jobs, that is, of available employment for wages. But if it be assumed, as Judge Willis assumed in granting a permanent injunction, that plaintiffs are "workers" with an interest in "jobs" like that of all other union nembers, $a$ fortiori denial of membership plus maintenance of a closed shop creates an unlawful monopoly of jobs as to plaintiffs. The fact that in this instance the union hurt the excluded workers by cutting their supply rather than their employer, is a change in weapons used to injure rather than in the substance of the right that is injured.

Judge Willis did not hold, however, that plaintiffs were victims of a monopoly. Instead relief was granted on the basis that a boycott is lawful only if its purpose is to subserve some "public interest" or "public welfare". In the instant case, the court observed, the union's purpose was "essentially selfish," that is, to appropriate ". . the jobs

97 Supra note 90.

98 In its notice to milk brokers requesting cessation of sale to plaintiffs, the union stated, "For some time Local Union No. 93 has been confronted with the problem of the independent peddler distributors who have been from time to time taking business from the legitimate wage eamers who are members of Local No. 93." (Italics added.) 
such independents have created for themselves as a means of livelihood and give them to members of the union." 99

The test thus adopted proves too much. Logically applied, it would bar most union activities which injure third parties, since the admitted purpose thereof is to benefit the membership's "self-interest". The answer, of course, is that the very "selfishness" which the court here chastises, by other courts, including the California Supreme Court, has been held to be "justification" for infliction of injury, on the theory that society as a whole benefits most by peaceful competition between selfish interests. ${ }^{100}$

99 "Under the magnanimous spirit of our Federal Constitution, conceived and adopted to guarantee the greatest freedom, and as liberally interpreted by our highest courts, labor unions have acquired a great power. That power should never be applied or used to work evil. Its use should never be employed under the banner of one freedom to cause the direct loss to others of rights of freedom guaranteed to them, in order to attain selfish or unnecessary purposes. Rules of conduct in applying such power in a given industry should always be reasonable and adopted and enforced only under the urge of the necessities of employment within such industry, and for the protection of the union members as workers therein. They should be reasonahly connected with controversies which affect workers in a given industry or occupation generally, or reasonably related to employment conditions generally, or to collective bargaining to improve such conditions. When so exercised public approbation is earned and the courts approve and justify the use of the power even though rights of others are incidently affected or impaired. The true test lies in the answer to the question: Is the power being exercised in the pursuance of public policy and for public welfare as such are related to those who constitute the workers in our land, either as a whole body or in some particular industry, business or occupation?

"The arbitrary deprivation, by pressure of union activities, of this right to work with one's hands for a livelihood goes beyond mere limitation in the public interest bereinbefore mentioned, and certainly is not a limitation necessary to subserve public welfare. The real purpose of the union in this case, as evidenced by its notice to the brokers supplying dairy products to plaintiffs, is not reasonahly connected with any controversy which affects workers in the milk industry generally, or any workers employed by plaintiffs-for they have no employees-nor is it reasonably related to employment or collective bargaining. Such purpose is essentially selfish and is outside of, and repugnant to, the recognized beneficient and legitimate purposes and activities of labor unions to improve the worker's condition, and to secure for him his place in the sunshime. Its attainment could, therefore, subserve no public interest. In conjunction witl the union's refusal to permit independents to join the union, the result of such accomplished purposes is liquidation of such independents in the comnunity with the object of appropriating the jobs such independents have created for themselves as a means of livelihood and giving thein to inembers of the union."

100 "The defendants were seeking, in all they are shown to have done, to secure employment by the plaimtiff for themselves, to the exclusion of those not associated with them, and to secure that employment upon terms deemed satisfactory or advantageous to them. That is the effort of every dealer in goods; it is the struggle of competition, and is no more to be frowned upon where the subject of trade is labor than where it is a specific commodity." Concurring opinion of Sloss, J., in Parkinson Co. v. Building 
Unlareful means. ${ }^{101}$-The 18 th Century economists who preached laissez faire and damned the era of paternalism in government that preceded, never ventured to suggest that men be free to compete by violence, libel or other means that exceed the limits of economic pressure. Nor did the judges who converted laissez faire economics into laissez faire legal theory. On the contrary, it was umiversally assumed that the principal job of government was to police the conflict whenever competition exceeded the limits of economic pressure. ${ }^{102}$ Controversy existed, however, as to where economic pressure left off and unlawful means of competition began.

The latter-day tendency of judges has been to extend the concept of permissible pressure so as to permit moral and social as well as economic pressure previously banned as intimidation or coercion. ${ }^{103}$ This

Trades Council, supra note 2, at 607, 98 Pac. at 1038; McKay v. Retail Auto S. L. Union, supra note 6, at 326, 106 P. (2d) at 381. Quoted with approval was Chief Justice Beatty's statement in the Parkinson case, "In order to secure employment on more favorable terms for themselves, individuals have an absolute right to combine for the purpose of preventing employment and competition of others." Ibid.

"Everyone who enters the field of competition desires and plans to draw custom from his competitors. Unless his acts are unlawful, his avarice is not actionable.' [Quoting American Auto. Ass'n v. American Auto. O. Ass'n (1932) 216 Cal. 125, 142, $13 \mathrm{P}$. (2d) 707,715$]$.... 'The fact that the methods used were ruthless, or unfair, in a moral sense, does not stamp them as illegal. . . . The justification for such conduct is said to be that free competition is generally considered worth more to society than it costs. [Holmes, J., dissenting in Vegelahn v. Guntner (1896) 167 Mass. 92, 106, 44 N. E. $1077,1079$.$] . . . . The underlying reason beneath these rules is a widespread behef in$ competition, free enterprise, and equahity of opportunity." C. S. Smith Metro. Market v. Lyons, supra note 29, at 399, 106 P. (2d) at 420.

101 "We think, therefore, that associations may be entered into, the object of which is to adopt measures that may have a tendency to impoverish another, that is, to diminish his gains and profits, and yet so far from being criminal or uulawful, the object may be highly meritorious and public-spirited. The legality of such an association will therefore depend upon the means to be used for its accomplishment . . . a conspiracy must be a combination of two or more persons, by some concerted action, to accomphish some criminal or unlawiul purpose, or to accomphsh some purpose, not in itself criminal or unlawful, by criminal or unlawful means. We use the terms criminal or unlawful, because it is manifest that many acts are unlawful, which are not punishable by indictment or other public prosecution...." Shaw, C. J. in Commonwealth v. Hunt, supro note 1, at 138 .

102 C. S. Smith Metro. Market v. Lyons, supra note 29, at 398-399, 106 Pac. at 420.

103 In re Bell (Feb. 13, 1942) 19 Cal. (2d) 488, 497, 122 P. (2d) 22, 28, denying nine members of the C. I. O. United Cannery, Agricultural and Allied Workers Union a writ of habeas corpus against confineinent under a Yuba County Ordinance punishing violence in picketing, where petitioners had "failed to sustain the burden of proving that they were not convicted" under the valid section prohibiting violence.

"The fact that to some extent compulsion, coercion, intimidation, or threats are employed does not detract from its peaceful nature so long as they constitute only 
has been done by defining such pressure as a form of freedom of contract, ${ }^{104}$ speech, press or assembly directed toward an object (economic improvement of the status of workers) which the public is interested to promote. ${ }^{105}$ Thus the labor boycott which began as conspiracy, coercion, restraint of trade ${ }^{108}$ or inducement of breach of contract, ${ }^{107}$ in the hands of liberal judges became a form of freedom of contract (freedom to withhold patronage).$^{108}$ And picketing which began by being classed with ". . . chaste vulgarity, or peaceful mobbing, or lawful lynching", ${ }^{109}$ today is classed as free speech, even though ". . . to some extent compulsion, coercion, intimidation, or threats are employed. ..."110

Only in the case of actual violence or serious threat thereof is the classic concept of illegal pressure still more or less universally employed.11 But since circumspect judges felt constrained by agency theory from punishing unions as principals because of unauthorized violence or threat thereof by individual members, ${ }^{112}$ some unions

economic, moral, or social pressure and not the pressure of violence." $C f$. New Negro Alliance v. Grocery Co. (1937) 303 U.S. 552; In re Lyons (1938) 27 Cal. App. (2d) 182, 80 P. (2d) 745.

104 "If it be true that workingmen may coinbine with a view, among other things, to getting as much as they can for their labor, just as capital may combine with a view to getting the greatest possible return, it must be true that when counbimed they have the same liberty that coinbined capital has to support their interests by argument, persuasion, and the bestowal or refusal of those advantages which they otherwise lawfully control." Holnes, J., dissenting in Vegelahn v. Guntner, supra note 85, at 108.

105 "It is true that the rights of employers and employees to conduct their economic affairs and to compete with others for a share in the products of industry are subject to modification or qualification in the interests of the society in which they exist. This is but an instance of the power of the State to set the limits of permissible contest open to industrial combatants. See Mr. Justice Brandeis in [Duplex Printing Press Co. v. Deering] 254 U.S. at 488 . It does not follow that the State in dealing with the evils arising from industrial disputes may impair the effective exercise of the right to discuss freely industrial relations that are matters of public concern. A contrary conclusion could be used to support abridgement of freedom of speech and of the press concerning almost every matter of importance to society." Murphy, J., holding an Alabama antipicketing statute unconstitutional in Thornhill v. Alabama (1940) 3I0 U.S. 88, 103.

108 Casey v. Cincinnati Typographical Union (C.C.D. Ohio 1891) 45 Fed. 135, 143; Quinn v. Leathem [1901] A.C. $495,508$.

107 Truax v. Raich (1915) 239 U.S. 33; Auburn Draying Co. v. Wardell (1919) 227

N. Y. 1,124 N. E. 97.

108 Supra note 104.

109 Moore v. Cooks, etc. Union (1919) 39 Cal. App. 538, 541, 179 Pac. 417, 418.

110 In re Bell, supra note 103, at 497, 122 P. (2d) at 28.

III Ibid.

112 United States v. International Fur Workers Union (C. C. A. 2d, 1938) $100 \mathrm{~F}$. (2d) 541, 547; Nann v. Raimist (1931) 255 N.Y. 307 , 174 N. E. 690; Sweetman v. Barrows (1928) 263 Mass. 349,161 N. E. 272; cf. Commonwclth v. Hunt, supra note 1 , at 129. 
could and did take the risks of individual liability in exchange for the promotional benefits of violence. Eventually, therefore, even circumspect judges concluded that notwithstanding agency theory, ${ }^{113}$ picketing by a union would be prohibited entirely where the number and duration of individual acts of violence is enough to indicate a pattern of violence in which otherwise peaceful picketing is "enmeshed". ${ }^{114}$

The Labor Relations Department has extended rather than limited the bounds of permissible union pressure. Following California Supreme Court precedent, ${ }^{115}$ Judge Willis early refused to enjoin a union from describing an employer as "unfair", the word being construed as a word of art rather than defamatory description when used in a labor dispute. ${ }^{116}$ Denying a cross-complaint for libel arising out of another labor case, ${ }^{117}$ the court held that a union's propaganda to prospective nembers is "a commumication to a person interested therein by one who is also interested" within the Civil Code definition of qualified privilege. ${ }^{118}$

In Evans v. J. L. Cooper, ${ }^{119}$ however, the court enjoined use of epithets, pickets in excessive number and endless chain marching, as "intimidation". And in American Union Alliance v. A.F. of $L .{ }^{120}$ the court held that a complaint based on use of threats of physical force in promoting union membership in a company union plant stated a cause of rehef. But in White Cab Co. v. Chauffeurs Local $640^{121}$ the court denied that individual acts of violence or intimidation even when multiplied and extended in time could justify a complete ban

113 "And in exercising its power a state is not to be treated as though the technicalities of the laws of agency were written into the Constitution. Certainly a state is not confined hy the Constitution to narrower linits in fashioning remedies for dealing with industrial disputes than the scope of discretion open to the National Labor Relations Board. It is true of a union as of an employer that it may be responsible for acts which it has not expressly authorized or which might not be attributable to it on strict application of the rules of respondeat superior." Frankfurter, J., in Drivers' Union v. Meadownioor Co. (1941) 312 U. S. 287, 295.

114 Steiner v. Long Beach Local No. 128 (March 3, 1942) 19 Cal. (2d) 676, 123 P. (2d) 20.

115 Parkinson Co. v. Building Trades Council, supra note 2.

118 Glendale Lumber Co. v. Lumber Mill \& Cabinet Workers Union (L. A. Super. Ct. No. 437252, April 20, 1930) L. A. DaIrY J.

117 Daniels v. Table Linen Supply Co., supra note 49 (the union had described the einployer as a would-be "American Hitler").

118 Cat. Crv. Code $\$ 47$ (3) (1).

119 (L. A. Super. Ct. No. 470728, Dec. 24, 1941) L. A. DaIIY J.

120 Supra note 83.

127 (L. A. Super. Ct. No. 455171, June 9, 1941) L. A. Darry J. 
on picketing. Distinguishing Drivers' Union v. Meadowmoor Co. ${ }^{122}$ as merely permitting but not requiring a state to issue an unlimited injunction in such circumstances, ${ }^{123}$ Judge Willis concluded,

\begin{abstract}
"California has however chosen a different path and shaped a different policy over a long period of years in respect to enjoining peaceful picketing. ... It is the policy of the State of California to protect the right of peaceful picketing, and to deny the courts of the state the power to enjoin the exercise of suclı right. ${ }^{124}$ But the courts still retain the power in this state to enjoin wrongful acts and conduct committed or threatened in the course of a strike or of picketing. In short, the courts may comb out the unlawful activities by injunctive process, leaving, lowever, intact the constitutional riglit to picket peaceably."
\end{abstract}

In Steiner v. Long Beach Local No. 128, ${ }^{12 x}$ however, the California Supreme Court took a different view of California policy than had the Labor Relations Department. Approving the doctrine of the Meadowmoor Dairies case, the court stated,

"Accordingly, where past picketing has become so irrevocably blended with acts of violence, physical intimidation or other unlawful conduct as to give rise to justifiable belief that future picketing is likely to result in a continuance of illegal acts, an injunction restraining a labor organization from any and all picketing lies within the equitable power of the court and does not constitute an infringement of the right of free speech." 126

\title{
OBJECTIVE: INDUSTRIAL PEACE
}

Until recently question existed im many jurisdictions as to whether collective bargaining agreements were enforceable. It was argued that the union reaped benefits but conferred no return consideration under

122 Supra note 113.

123 Relying on the following quotation from Frankfurter's opinion in the Meadownoor Dairies case, supra note 113, at 298, "We are here concerned with power and not with the wisdom of its exercise. We merely hold that in the circumstances of the record before us the injunction authorized by the Supreme Court of Illinois does not transgress its conditional power. That other states have chosen a different path in such a situation indicates differences of social view in a domain in which states are free to shape their local policy."

124 Relying on Pierce v. Stablemen's Union, supra note 2; Southern Cal. Co. v. Amalgamated Ass'n (1921) 186 Cal. 604, 200 Pac. 1. Both of these decisions, however, held picketing illegal per se. Neither Lisse v. Local Union No. 31 (1935) 2 Cal. (2d) 312, 41 P. (2d) 314, nor the McKay case, supra note 6, also relied on, involve a pattern of past violence involved in the instant circumstances before the Labor Relations Departinent.

125 Supra note 114.

126 Ibid. at 683,123 P. (2d) at 24. 
such agreements, since the union often did not expressly agree to supply workers, and even if it did, could not be compelled to perform. ${ }^{127}$ Most courts eventually resolved the question as to consideration by mferring a duty of the umion to supply workers, and distimguishing between the non-compellable promise of a particular employee to work and the compellable promise of a union to supply men from among a general group. ${ }^{128}$ This interpretation was frequently premised on the stated basis that enforcement of collective bargaining agreements promotes "industrial peace". ${ }^{120}$

From the duty to supply workers the negative duty not to permit the workers to strike without cause was sometimes implied, where not expressed. ${ }^{130}$

In Shop'N Save Corp. v. Retail Food Clerks Union, ${ }^{131}$ decided prior to creation of the Labor Relations Department, Judge Willis in effect compelled performance of a collective bargaining agreement by enjoining picketing in support of a strike called without prior compliance with an arbitration clause. Even without an arbitration clause, the Labor Relations Department in Doyle v. American Window Clean-

127 Wilson v. Airline Coal Co. (1933) 215 Iowa 855, 246 N.W. 753 ; Davis v. Davis (1926) 197 Ind. 386, 151 N.E. 134; Hudson v. Cincinnati, N. O. \& T. Ry. (1913) 152 Ky. 711, 154 S.W. 47; Weber v. Nasser (Cal. D.C.A. 1930) 286 Pac. 1074, superseded in Weber v. Nasser (1930) 210 Cal. 607, 292 Pac. 637, on ground that expiration of term of agreement made issue moot.

128 See cases summarized in ZISKIND, op. cit. supra note 1, at 2-6.

"Section 3390, sub. 1 of the Civil Code provides that an obligation to render service cannot be specifically enforced. Herein the obligation souglit to be enforced does not include the rendition of personal service. The obligation assumed by defendant and herein souglit to be enforced is to hire all persons as wimdow cleaners in its business from the union employment office. The obligation assumed by the plaintiff was to supply window cleaners for service. The agreement is with the umion as an entity and is not an agreement to hire or to furnislı any particular individual for service." Doyle v. American Window Cleaming Co. (L. A. Super. Ct. No. 457128, June 16, 1941) L. A. DaIIY J.

129 Harper v. I. B. E. W. (Tex. Civ. App. 1932) 48 S.W. (2d) 1033.

130 A. R. Barnes \& Co. v. Berry (C.C.D. Ohio 1907) 156 Fed. 72 ; Burgess v. Georgia, F. \& A. Ry. (1918) 148 Ga. 415, 96 S.E. 864; Preble v. Architectural, etc. Union (1931) 260 III. App. 435.

181 (L. A. Super. Ct. No. 448324, May 1, 1940) L. A. DaIry J. "Nevertheless many collective bargaining contracts contain provision for conclusive arbitration, and whether, in this state, such provisions may be enforced by court process or not, they are the lawful, deliberate and presumably good faith acts and promises of both parties, and in good conscience and in equity binding on both. Such a provision for arbitration of controversies in a collective bargaining contract contains an implied promise not to strike and use economic pressure to force agreement with labor's demands. Hence a repudiation of a voluntary arbitration agreement followed by strike and picketing is an unjustifiable breach of contract even though such arbitration procecdings cannot be compelled or enforced by court process under state law." 
ing $\mathrm{Co}^{132}$ held that a strike for higher wages during the term of the agreement was a breach, barring the union from later compelling specific performance by the employer.

In Warehouse Workers Union v. Sontag \& Thrifty Drug Stores ${ }^{133}$ the problem was whether an industrial union breached its closed shop contracts by calling a strike of members not covered by the contracts for the purpose of compeling the employer to extend the closed shop to such employees. The Labor Relations Department held that the union had breached its contracts, thereby disentitling itself to decree for specific performance. ${ }^{134}$

The rule thus established favors the craft as against the industrial form of umion. For, notwithstanding mutual affiliation through the American Federation of Labor, a craft union representing the uncovered classification of employees, pharmacists in the instant case, could have called a strike for a closed shop without affecting an existing contract of another craft union or unions covering other classifications. ${ }^{135}$

132 Supra note 128. "From the foregoing it clearly appears that the plaintiff umion destroyed all pre-existing mutuality of the agreement by its repudiation of the agreement and cessation of performance, and its deliberate act of calling a strike against defendant and picketing its jobs thereafter. And it must be held that calling off the strike and offering to perform in a perfunctory obligation in a complaint for specific performance did not have the effect of restoring such former mutuality."

133 (L. A. Super. Ct. Nos, 468896, 468923, Nov. 22, 1941) L. A. DaIry J. The contracts provided that the union and its members would not engage in "... any strikes, slowdowns or stoppages of work ..." but also provided that the employees could refuse to cross any ". . . bona fide picket line recognized by the union."

134 "Furthermore, to construe these provisions relating to strikes, under the language used, in the manner and to the effect urged by the plaintiffs, would produce and involve an absurdity in that such construction would permit the union, at will, to destroy the main and essential consideration moving to the defendants, namely, industrial peace and freedom from strife between the defendants and the union. To avoid or stop one strike or threatened strike by a contract authorizing another strike would be indulging in absurdity."

135 This result is in apparent conflict with McKay v. Retail Auto S. L. Umion, supra note 6, at 325, 106 P. (2d) at 381, where the California Supreme Court stated, "The fact that the defendant umons are craft organizations does not preclude them from consolidating to obtain an industrial bargaining unit. (See 6 Chicago L. Rev. 675.) The complaint alleges that these unions are affiliated with the American Federation of Labor, and also that they are members of the defendant Labor Council. This indicates that they are proceeding with some unity toward the objectives they seek. To hold, as the plaintiffs insist the court should, that separate organizations may not jom forces in labor controversies for the purpose of obtaining a closed shop would establish a rule of law discriminating against the labor groups in this state which are organized horizontally, or into crafts, and in favor of the vertical or industrial type of union. For if the other employees of the company belonged to a single union they would be privileged, under the Califorria anthorities, to engage in any peaceful and lawful activities in order to compel the members of the sales department to join their union." (Italics added.) 
In Barnes v. Angelus Paper Box Co.$^{136}$ the court went still further, holding in effect that a union signing a closed shop contract in effect guarantees "industrial peace" to the employer. Thus the court denied the complainant union specific performance because it had failed to prevent strikes and picketing by a rival union ${ }^{137}$ claiming exclusive jurisdiction under the parent American Federation of Labor, with which both umions were affiliated,

"The loss or failure to bring industrial peace deprives the employer of the very essence of the consideration which he was promised and which he expected. If such loss is due to the fault of the contracting union, to that extent the union has failed to perforn its obligation. ... Until the controversy concerning authority to bargain now existing between these two locals is deternined by the tribunals of their own parent organization, to whose decision and discipline they are equally subject, or by some other legal process, this court of equity will dechine to act in any manner other than to leave the parties as they are now situated."

The decision seems questionable. For the rule of exhaustion of remedies as here applied concerns disputes within trade unions, rather than actions between unions and employers. ${ }^{138}$ Further, the California Suprenie Court has indicated that the employer in such circumstances may be entitled to relief as the victim of ". . . a true jurisdictional dispute between rival unions. . . ."130 If so, the employer is adequately protected against the disgruntled rival union, without necessity of denying specific performance of the union holding the closed shop contract.

\section{APPRAISAI}

In its sixteen month history, the Labor Relations Department has decided eighteen reported cases. These included four instances of alleged violence, intimidation or other unlawful neans used by unions

138 (L. A. Super. Ct. No. 467051 , Nov. 19, 1941) L. A. Danx J.

137 Rivalry existed between plaintiff Pulp, Sulphite and Paper Mill Workers and the International Printing Pressmen and Assistants Union. Plaintiff twice procured recognition and defendant employer's adherence to a closed shop following plaintiff's selection as hargaining representative by a large majority in "check-off elections". Notwithstanding prior agreement of both unions and the employer to abide by the results of the election, the disgruntled Pressmen's Union repudiated the election results both times striking and picketing to prevent the employer from performing its closed shop contract with plaintiff union.

138 Note (1936) 45 YALE L. J. 1248, 1262.

189 Suppra note 64. 
in connection with strikes, picketing or boycotting. ${ }^{140}$ Two involved efforts to control union activity by legislative enactment. ${ }^{141}$ Four were instances of dispute between rival unions. ${ }^{142}$ Two were efforts to curb alleged "unfair labor practices" by employers interfering with union organizational activities. ${ }^{143}$ Three cases involved, directly or indirectly, requested limitation of union power over internal union affairs, that is, nuembership. ${ }^{144}$ Four involved definition of rights and duties of employers and unions under collective bargaining agreements. ${ }^{145}$

The Department's statistics suggest two conclusions. First, there is a tendency of workers as well as management to fight their problems in the Department rather than "on the streets". ${ }^{40}$ Secondly, these problems run the ganiut of management-labor and intra-labor relationships.

The Department's reported decisions reveal the following characteristics in its treatment of labor problems. First, they reveal sincerity, care and circumspection on the part of the court. Secondly, they show a tendency of the court to keep its decisions abreast of public opinion on labor problems, even at the risk of accomplishing

140 American Union Alliance v. A. F. of L., supra note 83; Daniels v. Table Linen Supply Co., supra note 49; Evans v. J. L. Copper, supra note 119; White Cab Co. v. Chauffeurs Local 640, supra note 121.

141 Nelson v. Los Angeles Bldg. Trades Council, supra note 22 ; Nash Co. v. Retail Food Clerks Union, supra note 68.

142 Pfeiffer v. Borun Bros., supra note 59; Kaufnan v. Amalgamated Meat Cutters \& Butchers, supra note 60; Adkins v. Western Pipe \& Steel Co., supra note 61; Los Angeles County Fair Ass'n v. Pomona Valley Central Labor Council, supra note 67.

${ }^{143}$ Coleman v. Back, supra note 44; Daniels v. Table Linen Supply Co., supra note 49 .

144 Stockwell v. Vinstrand Theatres, supra note 66; Dyar v. International Photoggraphers Union, supra note 89 ; Bautista v. Milk Drivers Union, supra note 90.

145 Doyle v. American Window Cleaning Co., supra note 132; Warehouse Workers Union v. Sontag \& Thrifty Drug Stores, supra note 133; Barmes v. Angelus Paper Box Co., supra note 136; Printing Specialties \& Paper Converters' Union v. Capital Envelope Co. (L. A. Super. Ct. No. 487181, Aug. 3, 1942) L. A. DAIIY J. [denying union's request for decree conipelling discharge of a non-union employee who refused niembership, where the contract between union and eniployer failed to specify the duty to discharge although specifying that non-neinber employees "... shall make application within thirty (30) days to become a member of the union."]

140 "Plaintiffs have pursued a wise course in submitting their difficulties to the court for adjudication instead of resorting to the picket line. Labor organizations seem to have assumed heretofore that the courts would grant injunctions only at the suit of an employer and too frequently have made use of other means of obtaining redress for their grievances. Differences between employees and employers can and should be settled in the courts instead of on the street." Wilson, J., in Althof v. Western Aeronautical Supply Mfg. Co., supra note 44 . 
by judicial decision what the legislature failed to accomplish by enactment. Thirdly, they reveal the lack of an integrated system of labor law with which to meet the problems, due to the fact that the available judicial tools consist of a hodge-podge of laissez faire extracted from the common law and incomplete public control by legislation extracted from the needs of modern complicated society.147 Finally, they show that creation in the community of a single public agency, in this instance a court, to deal with labor problems, is an important step in the direction of coherence, integration and public acceptance of the law of labor relations.

147 The time is ripe-indeed overripe-for an attempt to treat the law of labor organization as a system of legal relations, rather than as a collection of bundles or groups of rules with no inner relation or unity. That we bave no such integrated system of the law of labor organization is made evident by the fact that, search as we may, we shall be unable to find either a generally accepted or a tolerably satisfactory answer to the question: What is a labor organization?

Nor is this the only question which baffles the student of our subject. If we turn from the question just put, which of necessity stands at the very outset of the consideration of our subject, to a question which concerns the most important relation of labor organization, namely, What is a collective bargaining agreement? we shall be confronted with the same difficulty. And what is even more disturbing, neither of these questions has ever been seriously put or adequately considered. And the same applies to all of the problems which he in between, or all around, the two questions just put. The law of labor organization has been growing at a tremendous pace, and the law reports as well as the law reviews are full of it. But the text writers, hike the opinion writers, usually deal with certain specific problems, to the utter neglect of the body of law as a whole. As a result there is no branch of the law which could properly be called the law of labor organization. One will search in vain for such a rubric in legal encyclopedias, from the American and English Encyclopedia of Law, first published in 1890, to the Restatement now in the process of publication. Boudin, Wanted: An Inlegrated System of Labor Law (Feb. 1942) 4 J. Por. 20. 